\title{
The difference of students' learning outcomes with project based learning using handout and sway Microsoft 365
}

\section{Nelius Harefa ${ }^{1 *}$, Novia Fransisca Dewi Silalahi ${ }^{2}$, Elferida Sormin ${ }^{1}$, Leony Sanga Lamsari Purba ${ }^{1}$, Sumiyati ${ }^{1}$}

\author{
'Department of Chemistry Education, Faculty of Teacher Training and Education, Universitas Kristen Indonesia, \\ Jakarta 13630, Indonesia \\ ${ }^{2}$ Chemistry Teacher of SMA Abdi Siswa Bintaro, Tangerang, Indonesia \\ ${ }^{*}$ Corresponding author: (NH); nelius.harefa@uki.ac.id
}

\begin{abstract}
:
This study aimed to determine the difference of students' learning outcomes with project based learning using handout and sway Microsoft 365. The sample was selected using purposive sampling into experimental group 1 and experimental group 11 with 64 students. The experimental group 1 used the project based learning using sway Microsoft 365, while the experimental group 11 used the project based learning using handout. The difference test between experimental group 1 and experimental group 11 student $t_{\text {count }}(5.411)>t_{\text {table }}(2.425)$ at significance $\alpha=0.05$, it concluded that there was the difference of students' learning outcomes used project based learning using handout and sway Microsoft 365.
\end{abstract}

Keywords:

Handout; learning outcomes; project based learning; sway Microsoft 365

\section{Introduction}

Learning innovations are needed to improve the quality of learning, improve the previous situation towards a better one, developing knowledge and insight, foster enthusiasm in work, and be able to adapt the era. Revolution Industry 4.0 era that requires learning systems to innovate in order to adapt these digital era. The digital era is closely related to learning media (Mustami, 2017; Dalimunte \& Suyanti, 2013). Learning media are objects that are most likely to be developed according to an era, learning media provide many options for innovation. Integration these media with interactive learning models such as project based learning can improve student learning outcomes.

Science materials such as chemistry are materials that require interactive learning models and innovative learning media so that they can adapt to the times and aren't considered ancient by students. The use of appropriate learning models can encourage the growth of student joy in learning increase motivation in doing assignment, and make it easier for students to understand the lessons, so that they achieve better learning outcome. Accuracy of the learning models can also increase student activities in the teaching and learning process (Silaban, 2017).

Project based learning is an interactive learning model based on projects that can be used in chemical material. Nainggolan et al. (2017), reports that giving assignments in the form of projects can improve students' learning outcomes on acid base materials. Projects given to students are effective to improve students' thinking skills (Anazifa \& Djukri, 2017). Thinking ability that is 
formed from the projects that are done by students can improve students' generic science skills (Dibyantini et al. 2018). Generic science skills of student's will influence learning outcomes, students with high generic science skills generally obtain high learning outcomes.

In addition to the cognitive field, the implementation of project based learning can improve students' abilities in the fields of affective and psychomotor skills. Students with improved psychomotor skills generally have good learning outcomes (Sumarni et al. 2016). Affective skills with Islamic value can improve environmental literacy students based on project (Farida et al. 2017). Therefore, implementation project based learning can improve the students' scientific literacy (Afriana et al. 2016).

Combining appropriate learning models and media can significantly improve learning outcomes. Generally, multimedia is suitable if integrated with interactive learning models such as project based learning, problem based learning, discovery learning, and inquiry learning (Suyanti \& Sormin, 2016). Multimedia such as Microsoft frontpage can improve students' learning outcomes (Situmorang et al. 2013). However, multimedia is not always more influential than conventional media such as handouts. Purba et al. (2018), reports that student learning outcomes on the use of media handouts are higher than student learning outcomes in the use of macromedia flash. Media handouts can stimulate student curiosity so that there is an increase in learning activities that affect the increase in learning outcomes (Agustina et al. 2013). Based on description, the researcher compared the used of media handout and sway Microsoft 365 which are expected to improve students' learning outcomes.

\section{Methods}

The research was held at Yadika 9 Bintara High School, Bekasi, Jawa Barat in academic year 2018/2019. The study was conducted in class X MIPA $1(n=32$ students $)$ and class X MIPA $2(n=$ 32 students) in the oxidation-reduction material. Further, class X MIPA 1 as group experimental 11 and class X MIPA 2 as group experimental 1 using purposive sampling technique. The group experimental I was taught used project based learning using sway Microsoft 365 and group experimental $\mathrm{ll}$ which was taught used project based learning using handout. The research design is presented in Table 1.

Table 1

Research design

\begin{tabular}{llll}
\hline Group & Pretest & Treatment & Posttest \\
\hline Experiment l & $\mathrm{X}_{1}$ & $\mathrm{P}$ & $\mathrm{X}_{2}$ \\
Experiment II & $\mathrm{Y}_{1}$ & $\mathrm{Q}$ & $\mathrm{Y}_{2}$ \\
\hline
\end{tabular}

$X_{1}$ represents pretest score experiment 1 group and $Y_{1}$ represents pretest score experiment 11 group. $P$ represents treatment used project based learning using sway Microsoft 365 media and Q represents treatment used project based learning using handout. $X_{2}$ represents posttest score experiment 1 group and $Y_{2}$ represents posttest score experiment 11 group.

The test instrument is an objective test (multiple choice questions) that will be standardized and adjusted to the research topic. The test instrument consisted of 40 items with options $(a, b$, c, d, e) that must be answered according to the answer keys as respondents with the maximum score 100 and the minimum score 0 . The question items are designed to cover six cognitive regions according to Bloom's taxonomy C3 - C6.

The data were analyzed with descriptive quantitative analysis technique. The project based learning with sway Microsoft 365 media is effective when there is a difference between pre-test and post-test scores based on paired sample t-test. 


\section{Results}

\section{Students' learning outcomes}

The group experimental 1 was taught used project based learning using sway Microsoft 365 and group experimental 11 was taught used project based learning using handout on oxidationreduction material. Based on research data, the pretest values for each experimental class are presented in Table 2.

Based on the table, the average value of the group experimental 1 pretest was 62.50 with the highest score is 76.5 (scale of 100) and the lowest value is 33.5 (scale of 100). The average value of the pretest of the class is below the ideal score (standard learning completeness) at Yadika 9 Bintara High School, Bekasi, Jawa Barat. Referring to the average data on the pretest value, it can be seen that students in the group experimental 1 had good prior-knowledge about oxidationreduction material. Students with the highest score (76.5) were able to pass the ideal score on oxidation-reduction materials even though they had not been treated.

The average value of the pretest of group experimental 11 was 61.98 with the highest score is 75 (scale of 100) and the lowest value is 34 (scale of 100). The average value of the pretest of the class is below the ideal score (standard learning completeness) at Yadika 9 Bintara High School, Bekasi, Jawa Barat. However, referring to the data on the average value of the pretest, it was seen that students in the group experimental 11 had good prior-knowledge on oxidation-reduction material. Students with the highest score (75) were able to pass the ideal score on oxidationreduction materials even though they had not been treated.

After the pretest was done to find out the students' initial ability about oxidation-reduction material, the treatment was carried out in each experimental group. The group experimental 1 was taught used project based learning using sway Microsoft 365 media and the group experimental Il was taught used project based learning using handout. After completing the treatment, the final grade of student data (posttest) is taken, which is presented in Table 3.

Table 2

Description of the pretest value of students in each experimental group

\begin{tabular}{lllllll}
\hline Group & ldeal score & $\mathbf{N}$ & $\boldsymbol{x}_{\max }$ & $\boldsymbol{x}_{\min }$ & $\boldsymbol{x}$ & SD \\
\hline Experiment I & 75 & 32 & 76.5 & 33.5 & 62.50 & 11.80 \\
Experiment II & 75 & 32 & 75 & 34 & 61.98 & 11.25 \\
\hline
\end{tabular}

Table 3

Description of the posttest value of students in each experimental group

\begin{tabular}{lllllll}
\hline Group & Ideal score & $\mathbf{N}$ & $\boldsymbol{x}_{\max }$ & $\boldsymbol{x}_{\min }$ & $\boldsymbol{x}$ & $\mathrm{SD}$ \\
\hline Experiment I & 75 & 32 & 94.5 & 78.5 & 85.82 & 9.80 \\
Experiment II & 75 & 32 & 90.5 & 72 & 81.69 & 7.25 \\
\hline
\end{tabular}

Based on the table, the average value of the group experimental 1 posttest was 85.82 with the highest score is 94.5 (scale of 100) and the lowest value is 78.5 (scale of 100). Referring to the average posttest value, the highest value, and the lowest value, all students in the group experimental 1 passed the ideal score set by Yadika 9 Bintara High School, Bekasi, Jawa Barat on oxidation-reduction material.

The average value of the group experimental 11 posttest was 81.69 with the highest score is 90.5 (scale of 100) and the lowest value is 72 (scale of 100). Referring to the average posttest value and the highest value, all students in the group experimental class 11 passed the ideal score set by Yadika 9 Bintara High School, Bekasi, Jawa Barat on oxidation-reduction material. However, based on the lowest value, there are students who have not succeeded in passing the ideal score. 


\section{Implementation of handout and sway Microsoft 365 on students' learning outcomes}

To identify the effect of handouts and sway Microsoft 365 on students' learning outcomes is used project based learning models. The influence is based on students' pretest and posttest score. The data values of the pretest and posttest of each group experimental show differences. The difference in these values is presented in Fig. 1.

Based on the figure, it can be seen that the posttest value of each experimental group is higher than the value of the pretest. Thus, the implementation of the project based learning with handout and sway Microsoft 365 media influences students' learning outcomes in oxidation-reduction materials. Comparison of the value of the pretest and the posttest value of each experimental group is presented in Fig 2.

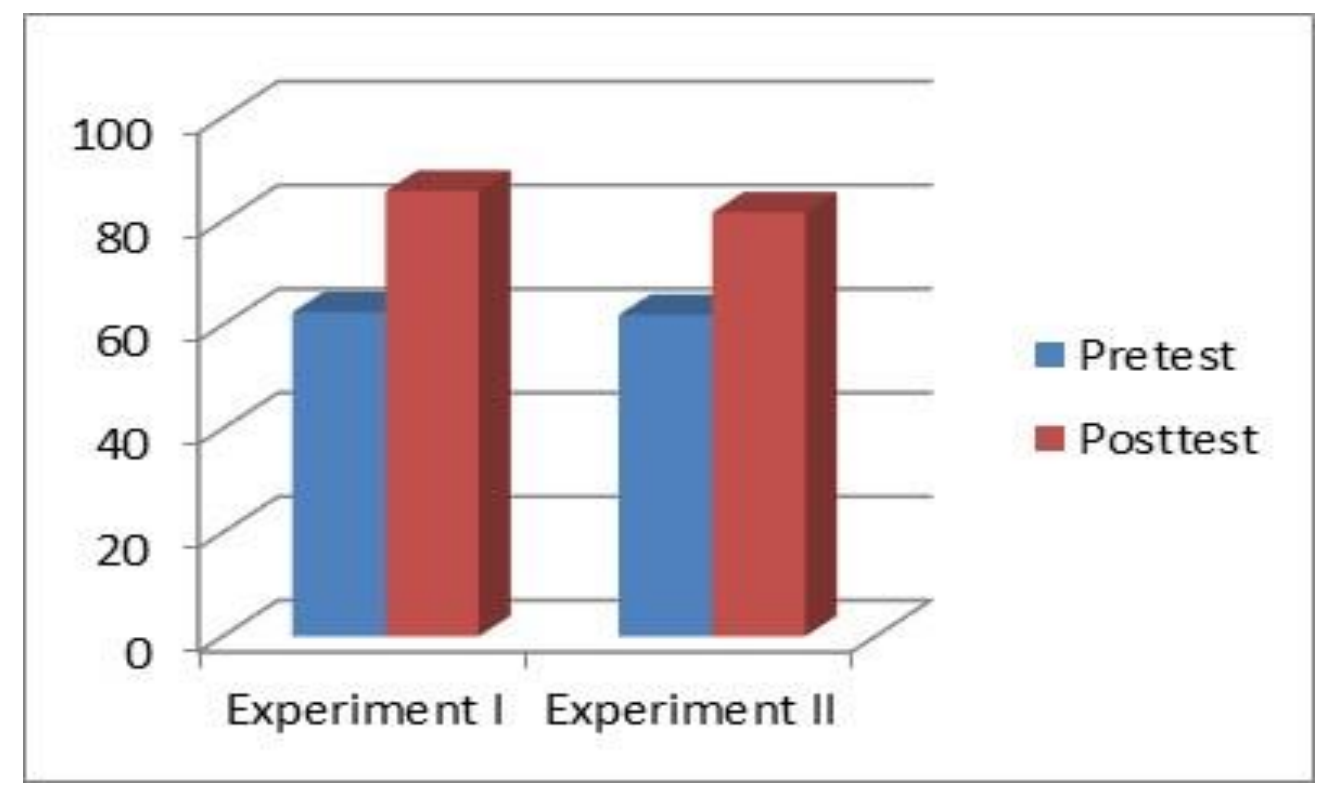

Fig 1. Comparison of the pretest and posttest values of each experimental group

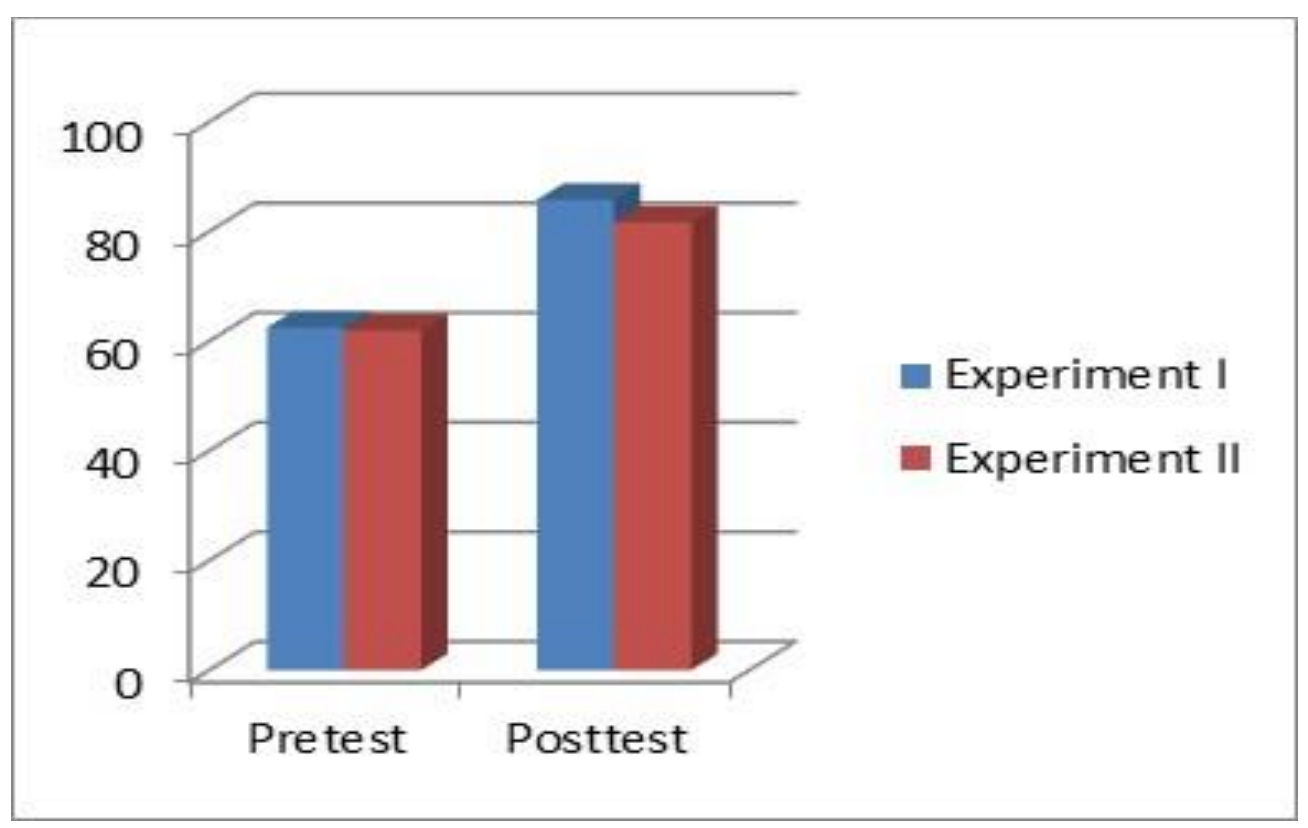

Fig 2. Comparison of the value of the pretest and the posttest value of each experimental group 
The average of pretest value in each experimental group has not reached the ideal score on oxidation-reduction material. While the average posttest value of the two classes has passed the ideal score which is the minimum score to achieve mastery learning at Yadika 9 Bintara High School, Bekasi, Jawa Barat on oxidation-reduction material. Thus, the use of sway Microsoft 365 and handouts can affect students' learning outcomes.

\section{Students' learning outcomes differences}

Based on the average value of the posttest of each experimental group, it can be seen the difference between the experimental 1 group was taught used project based learning using handout and sway Microsoft 365 media. These differences were analyzed by paired sample t-test presented in Table 4. Based on the table, the value of $t_{\text {count }}(5.411)>t_{\text {table }}(2.425)$ then there are differences in learning outcomes between students taught used project based learning using handouts and sway Microsoft 365 media at significance $\alpha=0.05$.

Table 4

Data hypothesis test of learning outcome

\begin{tabular}{llll}
\hline Group & & $\mathbf{t}_{\text {count }}$ & $\mathbf{t}_{\text {table }}$ \\
\cline { 1 - 2 } Experiment I & Experiment ll & & \\
$=85.82$ & $\mathrm{X}=81.69$ & & \\
$\mathrm{SD}=9.411$ & 2.425 \\
$\mathrm{~S}^{2}=62,74$ & $\mathrm{SD}=7.25$ & & \\
\hline
\end{tabular}

\section{Discussion}

Learning activities used project based learning is activity learning based on project who is given to students, the students can be create something in project according to the concept of the material (Santos et al. 2014). Creativity on the project can increase the students' understanding about the material which influences the improvement of learning outcomes (Nainggolan et al. 2018). Based on the analysis of research data, the implementation of project based learning using handout and sway Microsoft 365 can improve students' learning outcomes beyond the standard grade of mastery learning.

Handouts are media that are effective in improving students' learning outcomes, especially on theoretical chemistry materials. This media is generally in the form of books or papers that can be studied and discussed by students after learning class. Purba et al. (2018), reported that learning with the use of media handouts can improve students' learning outcomes and be higher than the learning outcomes of students who are taught using macromedia flash.

Sway Microsoft 365 is an application from Microsoft Office that helps collect data, format data, share ideas, share stories, and can be used as a web-based presentation media (Greve \& Strant 2012). In this media can be added text, images, documents, videos, charts, or other animations content (Kegg et al. 2017). Sway Microsoft 365 as a learning media can be used by students who are equipped with various animated features (Situmorang, 2013). These animations help students understand oxidation-reduction material which includes concepts and reactions that occur. Students can predict the oxidation-reduction material on some project integrated with animation on sway Microsoft 365. The predictive ability helps students in doing various examination tests. In addition, projects that have been done on Sway media can be stored on Microsoft 365 drives, can be accessed offline, and can be opened on Smartphone type Android. Millennial students prefer website-based learning to conventional learning (Harefa, 2019). Increasing the learning outcomes used project based learning using handout and sway Microsoft 365 has a significant 
difference at the significance level $\alpha=0.05$. While, students' learning outcomes used sway Microsoft 365 are higher than students' learning outcomes used handouts.

\section{Conclusion}

Based on the result data analysis, it can be concluded there was a difference in students' learning outcomes with project based learning using handout and sway Microsoft 365 on reductionoxidation reaction. The students' learning outcomes who taught used project based learning using sway Microsoft 365 are higher than students' learning outcomes who taught used project based learning using handout.

\section{Acknowledgments}

The author would like to express gratefulness to the Principal, Deputy Principal, Administrative Staff, Chemistry Teacher, and all student of SMA Yadika 9 Bintara who have helped the author during the research process.

\section{References}

Afriana, J., Permanasari, A., \& Fitriani, A. (2016). Project based learning integrated to STEM to enhance elementary school's students scientific literacy. Jurnal Pendidikan IPA Indonesia, 5(2), 261-267, doi: 10.15294/jpii.v5i2.5493

Agustina, E., Saputro, A.N.C., \& Mulyani, S. (2013). Penggunaan metode pembelajaran jigsaw berbantukan handout untuk meningkatkan aktivitas dan prestasi belajar siswa pada materi pokok hidrokarbon kelas xc sma negeri I gubug tahun ajaran 2012/2013. Jurnal Pendidikan Kimia, 2(4), 66-71.

Anazifa, R. D., \& Djukri, D. (2017). Project-based learning and problem-based learning: Are they effective to improve student's thinking skills?. Jurnal Pendidikan IPA Indonesia, 6(2), 346-355, doi:10.15294/jpii.v6i2.11100

Dalimunthe, M., \& Suyanti, R. D. (2013). Pembentukan karakter dan peningkatan hasil belajar kimia siswa sma melalui pengintegrasian strategi dan media pembelajaran pada materi hidrokarbon. Jurnal Pendidikan Kimia, 5(02).

Dibyantini, R. E., Silaban, R., \& Suyanti, R. D. (2018). The implementation of problem based learning model in improving the generic science skill of organic chemistry on teacher candidates. Proceedings of the 3rd Annual International Seminar on Transformative Education and Educational Leadership (AISTEEL 2018), doi:10.2991/aisteel-18.2018.136

Farida, 1., Hadiansah, Mahmud, \& Munandar, A. (2017). Project based learning design of internalization of environmental literacy with Islamic value. Jurnal Pendidikan IPA Indonesia, 6(2), 277-284, doi: 10.15294/jpii.v6i2.9452

Greve, D., \& Strant, L. (2012). Microsoft office 365: Exchange online implementation and migration. Birmingham: Packt Publishing.

Harefa, N., Gultom, S., \& Purba, L. S. L. (2019). Implementasi webinar terhadap sikap sadar keamanan kimia mahasiswa. Jurnal Dinamika Pendidikan, 12(1), 17-28.

Kegg, D., Guilmette, A., Mandich, L., \& Fisher, E. (2017). Microsoft office 365 administration inside out. United States of America: Pearson Education Inc.

Mustami, M. K. (2017). Inovasi model-model pembelajaran bidang sains untuk meningkatkan hasil belajar mahasiswa. Lentera Pendidikan: Jurnal Ilmu Tarbiyah dan Keguruan, 12(2), 125-137, doi: $10.24252 / \mathrm{lp} .2009 \mathrm{v} 12 \mathrm{n} 2 \mathrm{al}$

Nainggolan, B., Pinem, I.S.A., \& Hutabarat, W. (2018). Development of chemical practice guides class XI project based to improve student's chemical learning outcomes on acid based materials. Jurnal Pendidikan Kimia, 10(2), 393-396, doi:10.24114/jpkim.v10i2.11018 
Natalia Purba, D., Damanik, M., Silaban, S., \& Simatupang, L. (2018). The difference of student's activities and learning outcome with problem based learning using macromedia flash and handout. Jurnal Pendidikan Kimia, 10(3), 403-408, doi: 10.24114/jpkim.v10i3.12704

Santos, D.M., Montes, A., Coronilla, A.S., \& Navas, J. (2014). Sol-gel application for consolidating stone: an example of project based learning in a physical chemistry lab. Journal of Chemical Education, 91(2), 1481-1485, doi: 10.1021/ed4008414

Silaban, S. (2017). Dasar-dasar pendidikan matematika dan ilmu pengetahuan alam. Medan: Harapan Cerdas Publisher.

Situmorang, 1. G., \& Suyanti, R. D. Mahmud. (2013). Pengaruh model pembelajaran inkuiri dengan menggunakan media microsoft frontpage dan aktifitas belajar terhadap hasil belajar ipa siswa pada pokok bahasan zat aditif kelas viii smp. Jurnal Pendidikan Kimia, 5(3), 139-147.

Sumarni, W., Wardani, S., Sudarmin, \& Gupitasari, D.N. (2016). Project based learning to improve psychomotoric skills: a classroom action research. Jurnal Pendidikan IPA Indonesia, 5(2), 157163, doi: 10.15294/jpii.v5i2.4402

Suyanti, R. D., \& Sormin, E. (2016). Inquiry learning based multimedia towards the student's achievement and creativity on topic chemical bonding. US-China Education Review, 6(12), 701707, doi: 10.17265/2161-623X/2016.12.004 